\title{
The Influence of Labor Wages and Creativity on the Production Value of Troso Ikat
}

\author{
Royke Uswatun Khasanah ${ }^{1}$, Damas Gianluigi Alrizqi ${ }^{*}{ }^{*}$, Muhammad Feriady $^{1}$, \\ Nina Farliana ${ }^{1}$
}

${ }^{1}$ Universitas Negeri Semarang

*Corresponding author. Email: damasgianlugi@students.unnes.ac.id

\begin{abstract}
This study aims to determine the effect of labor wages on production value, the impact of creativity on production value, and the effect of labor wages and creativity on the production value of the ikat business in Troso Village, Jepara. This study uses quantitative methods and a causality research design. The population is weaving entrepreneurs in Troso Village, Jepara, amounting to 443 entrepreneurs with a sample of 82 respondents. The data collection tool uses a questionnaire. Data analysis used multiple linear regression analysis and hypothesis testing. The results of the study indicate that there is a positive influence on the cost of labor wages on the production value of the ikat weaving business; there is a negative effect of the creativity variable on the production value of the ikat business, and there is a positive influence on the cost of labor wages and creativity simultaneously on the production value of the ikat business. The value of the regression coefficient of the variable cost of labor wages was obtained by 0.924 percent. In contrast, the value of the regression coefficient of the variable of labor cost was obtained by -0.071 . Suggestions for this research for ikat entrepreneurs are to pay more attention to the wages of weaving workers, not just to meet the UMR of Jepara and for local governments to provide training to weaving artisans so that artisans have efforts to increase the production value of the weaving business.
\end{abstract}

Keywords: Production Value, Creativity, labor Wages, Troso Ikat

\section{INTRODUCTION}

Weaving industry centers are found in various regions in Indonesia, even almost every province in Indonesia has weaving production centers with the motifs and characteristics of each region. Based on data from the Indonesian Ministry of weaving industry centers on Java, there are 368 centers with 14,618 business units and employing around 57,972 people. In Central Java province itself, there are several weaving industry centers such as Tegal, Pemalang, Pekalongan, Batang, Jepara, Wonosobo, Sukoharjo, Klaten, and Sragen. Of these areas, one of the important weaving industry centers in Central Java is in Jepara, with a total of 443 business units.

Jepara is a city located in the corner of Central Java. Besides being known as a carving city because of its carvings which have its characteristics, Jepara also has several industrial centers that are developing, one of which is the weaving industry. The area known in Jepara as the center of the weaving industry is Troso Village.

In production activities, several factors need to be considered for the smooth production process, one of which is the cost of labor wages. According to Law no. 13 of 2003 concerning Manpower, wages are defined as the rights of workers/laborers received and expressed in the form of money as a reward from the entrepreneur or employer to the worker/laborer, which is determined and paid according to a work agreement, agreement, or statutory regulations including allowances for workers. Workers and their families for a job or service that has been or will be performed. The addition of the wage level will cause the value of industrial production to increase [4]. Based on this statement, the company is required to provide 
appropriate salaries or wages for workers because it is directly related to work spirit, receiving appropriate wages/salaries can increase enthusiasm to work in the company concerned, but if the wages/salaries received are not appropriate What is expected by workers, this will reduce employee morale which will have an impact on production results. This statement is in line with research conducted by [2] with the title The Effect of Minimum Wage on Firm Markup: Evidence from China which states that the minimum wage has a positive influence on companies and production values so that if companies give the wages to workers increases, the value of production will also increase.

Another factor that affects the value of production is creativity. Creativity is the ability to develop new ideas and to find new ways of solving problems and finding opportunities [9]. Creativity is part of entrepreneurial managerial skills that can determine the production results of a business. According to [10] someone has entrepreneurial skills if they make creative and innovative efforts by developing ideas and running resources to find opportunities and improvements in life. If an entrepreneur has high skills in creativity, it can facilitate the entrepreneur in making new concepts and ideas to develop their products. This can increase the demand for a business product, which can increase the production value of a business. Creativity is the main driver of economic development in industrial production. Therefore it is essential to produce a more detailed understanding of the entrepreneurial mindset in an effort to increase creativity.

Even though they have been struggling with the weaving industry for a long time, there are still some problems that entrepreneurs and weaving craftsmen have to face until now. The production value of the weaving industry in Jepara has changed from year to year. The following table presents the development of the value of weaving production in Jepara .

Table 1. Development of Weaving Production Value in Jepara in 2016 - 2018

\begin{tabular}{ll}
\hline Year & Production Value \\
\hline $\mathbf{2 0 1 6}$ & Rp.596.167.404.000,00,- \\
$\mathbf{2 0 1 7}$ & Rp.583.550.104.000,00,- \\
$\mathbf{2 0 1 8}$ & Rp.563.835.105.000,00,- \\
\hline
\end{tabular}

Table 1 shows that the value of weaving production in Jepara has decreased from 2016 to 2018. In 2017 the value of the weaving industry in Jepara decreased by Rp. 12,617,300,000.00, - while in 2018 it decreased by Rp. 19,714,999,000, 00,-. The decline in the value of the weaving industry from 2016 was due to a new industry entering Jepara, causing many workers to switch to work in other industries such as garments that promise high wages.

In line with the initial observations made by researchers in Troso Village, weaving entrepreneurs complained about several things related to the large number of workers who chose to switch to work in Foreign Investment (PMA) factories. The emergence of PMA companies that entered Jepara caused the weaving workers to prefer to work in these factories to guarantee more significant and more stable wages. Troso Weaving business owners must be smart in determining workers' wages so that more workers do not choose to switch to PMA factories and do not harm the company itself. There are several specifications for workers in the Troso Ikat Weaving industry: shovelers, ropers, designers, boom builders, unloaders, mallets, ministers, and weavers.

Most of the residents of Troso Village have a weaving business so that the competition in the Weaving industry is increasingly competitive, especially since Troso Weaving was made a civil servant uniform by the Governor of Central Java in 1980 which led to increasingly fierce competition because most Troso Village residents chose to become weaving entrepreneurs. The tight competition experienced by the weaving entrepreneurs requires the weaving entrepreneurs to have their own creativity to be able to develop the weaving motifs they produce so that they are not less competitive with other weaving entrepreneurs or with other textile entrepreneurs, and can be in demand by consumers both locally and internationally.

Based on observations, some weaving entrepreneurs have developed their woven motifs and products, but some entrepreneurs still maintain the old motifs. Creativity is a central role in entrepreneurship [3]. Creativity can be a determinant of the success of a business by creating new products so that consumers have an interest in buying products produced in a business so that the production value will be maintained and not decreased.

Based on this phenomenon, the authors are interested in conducting a study on "The Influence of Labor Costs and Creativity on the Production Value of Ikat Weaving Business in Troso Village, Jepara.". This study refers to previous research conducted by [5] entitled The Effect of Capital, Labor, and Technology on Monel Production Results (Case Study of Monel Industry in Jepara). Contribution to this research is taking the variable cost of labor wages and creativity. The taking of the creativity variable refers to the factors of production of entrepreneurial skills. Creativity is the main component in growing the entrepreneurial spirit and according to [8] entrepreneurship is the most decisive factor in production results. The main objectives of this study 
are: (1) To determine the effect of labor costs on the production value of the Ikat Weaving business in Troso Village, Jepara (2) To determine the effect of creativity on the production value of the Ikat Weaving business in Troso Village, Jepara (3) To determine the effect of the cost of labor wages and creativity simultaneously on the production value of the Ikat Weaving business in Troso Village, Jepara.

\section{METHOD}

This research is causal associative (cause and effect). This study uses a quantitative approach. The population in this study were all ikat weaving entrepreneurs, totaling 443 weaving entrepreneurs. Sampling using the Probability Sampling technique with the type of Simple Random Sampling with a total sample of 82 ikat weaving entrepreneurs in Troso Village, Pecangaan District, Jepara.

This study was conducted to determine the effect of labor costs and creativity on the production value of the ikat weaving business in Troso Village, Jepara. The dependent variable ( $\mathrm{Y}$ ) in this study is the production value of the ikat weaving business in Troso Village, Jepara which is measured by multiplying the production amount and the unit price of the product and expressed in rupiahs taken from 82 ikat weaving industry entrepreneurs in Troso Village, Jepara. The independent variables in this study are labor costs (X1) and creativity (X2).

The data collection method used in this research is a questionnaire (questionnaire) and observation. The questionnaire method in this study was carried out by giving a set of written questions to respondents who were entrepreneurs of troso ikat weaving by following the guidelines contained in the questionnaire. The questionnaire used in this study is an open and closed model questionnaire. An open questionnaire was used to collect data on labor costs and production values, while a closed questionnaire was used to collect data on creativity.

The test of the instrument was carried out using validity and reliability tests for the creativity variable. while the variable costs of labor wages and production value do not use validity or reliability tests because they use secondary data. Test the validity and reliability in this study using the help of the IBM SPSS Statistics 21 program. The data analysis method in this study used multiple linear regression analysis and hypothesis testing analysis. This study uses the double-log method by transforming all research variables into the form of the natural logarithm $(\mathrm{Ln})$, so that the regression model changes to the following:

$$
\operatorname{LnY}=a+b 1 \operatorname{LnX} 1+b 2 \operatorname{LnX} 2+e
$$

Information:
$\mathrm{Y}=$ Production Value

$\mathrm{A}=$ Constant

$\mathrm{b} 1, \mathrm{~b} 2$ = Coefficient of predictor regression equation $\mathrm{X} 1, \mathrm{X} 2$

Ln = Natural Logarithm

$\mathrm{X} 1$ = Labor Wage Cost Variable

X2 = Creativity Variable

$\mathrm{e}=$ Confounding Factor

\section{RESULTS AND DISCUSSION}

There are several product variants of ikat located in Troso Village, Jepara, for woven fabric products consisting of cotton woven fabrics, silk woven fabrics, and CSM with prices ranging from 70 thousand to millions rupiah. Meanwhile, other products include blankets, sarongs, headbands, scarves, tablecloths, bags, shoes and clothes.

\subsection{Labor Wage Cost}

The cost of labor wages is a payment given to all workers as remuneration from employers. Determination of wages in a company can determine the number of employees who will work and survive in a company. Wages can also be a separate motivation for workers, if the wages they get are following what they want, workers will feel their rights are fulfilled and can grow high enthusiasm to work harder so that the resulting production is more and of quality. The cost of labor wages in this study was measured by multiplying the number of workers, the number of products produced and the wages per unit and expressed in rupiah. The wages given by ikat entrepreneurs to workers are piece rates in accordance with the results of the work produced. Data on labor costs were taken from 82 ikat weaving entrepreneurs in Troso Village, Jepara.

Workers, in this case, are all workers in all stages of weaving, both daily workers such as masons and ministers as well as wholesale workers such as collectors, ropers, designers, boom builders, unloaders, and weavers. The following table shows the frequency distribution of labor costs provided by employers to troso ikat workers: 
Table 2. Variable Frequency Distribution of Labor Wage Costs

\begin{tabular}{cccc}
\hline No & $\begin{array}{c}\text { Labor Wage } \\
\text { Cost }\end{array}$ & Frequency & Presents \\
\hline 1 & $\begin{array}{c}1.500 .000- \\
4.669 .999\end{array}$ & 7 & $8,54 \%$ \\
& $\begin{array}{c}\text { 3.670.000 - } \\
2\end{array}$ & 31 & $37,80 \%$ \\
& 7.839 .999 & & \\
3 & $7.840 .000-$ & 20 & $24,39 \%$ \\
& 11.009 .999 & & $19,51 \%$ \\
4 & $11.010 .000-$ & 16 & $9,76 \%$ \\
& 14.179 .999 & & \\
5 & $14.180 .000-$ & 8 & $100 \%$ \\
\hline Total & 17.350 .000 & & \\
\hline
\end{tabular}

Based on the table above, it can be seen that the cost of labor wages issued by the company to all workers with the largest frequency is 31 entrepreneurs or $37.80 \%$ with labor costs ranging from $\mathrm{Rp}$. $4,670,000$ to Rp. $7,839,999$ and the smallest frequency, namely as many as 7 entrepreneurs or $8.54 \%$ with labor costs ranging from Rp. $1,500,000$ to $4,669,999$. Meanwhile, the mean (average) labor cost of troso ikat weaving is Rp. 8,855,292.68.

\subsection{Creativity}

Creativity is the ability to create new ideas and develop ideas to create something new. Creativity contributes to production because the high spirit of creativity by entrepreneurs will have an impact on the creation of superior, quality and competitive products. Creativity in this study is the level of creativity possessed by weaving entrepreneurs in Troso Village, Jepara in creating weaving motifs and models. Creativity in this study is measured using several indicators: creating, modifying, combining, and being original. Permanent workers are workers whose main job is as an engraver, while non-permanent workers are workers who are needed when there are many orders. This study's creativity data were taken from 82 ikat weaving entrepreneurs in Troso Village, Jepara. Creativity is needed in a business and production process, with the creativity of the production will have more value in the eyes of consumers. The following is a table of the frequency distribution of creativity owned by troso ikat entrepreneurs:
Table 3. Creativity Variable Frequency Distribution

\begin{tabular}{cccc}
\hline No & Creativity score & Frequency & Presents \\
\hline 1 & $12-21$ & 1 & $1,22 \%$ \\
2 & $22-31$ & 2 & $2,44 \%$ \\
3 & $32-41$ & 27 & $32,93 \%$ \\
4 & $42-51$ & 44 & $53,66 \%$ \\
5 & $52-60$ & 8 & $9,76 \%$ \\
\hline Jumlah & & 82 & $100 \%$ \\
\hline
\end{tabular}

Based on the table above, it can be seen that the creativity possessed by weaving entrepreneurs for business development with the largest frequency is 44 entrepreneurs or $53.66 \%$ with a creativity score between 42 to 50 and the smallest frequency is 1 entrepreneur or $1.22 \%$ with creativity score is between 12 to 21 while the mean (average) creativity of ikat entrepreneurs in Troso Village, Jepara is 43.51.

\subsection{Production Value}

Production value in this study is the production value of woven products produced by weaving entrepreneurs in Troso Village, Jepara in 1 week. The measurement of the production value in this study is by multiplying the amount of production by the unit price of each weaving product at weaving entrepreneurs in Troso Village for 1 week. Products produced by weaving craftsmen in Troso Village are silk, cotton, blankets, headbands, sarongs, and scarves. The following table shows the frequency distribution of the production value of troso ikat weaving:

Table 4. Variable Frequency Distribution of Production Value

\begin{tabular}{cccc}
\hline No & Production Value & Frequency & Presents \\
\hline 1 & $3.500 .000-$ & 9 & $10,98 \%$ \\
& 11.199 .999 & & \\
2 & $11.200 .000-$ & 46 & $56,10 \%$ \\
& 18.899 .999 & & \\
3 & $18.900 .000-$ & 19 & $23,17 \%$ \\
& 26.599 .999 & & \\
4 & $26.600 .000-$ & 7 & $1,22 \%$ \\
5 & 34.299 .999 & & \\
& $34.300 .000-$ & 1 & $100 \%$ \\
\hline Total & 42.000 .000 & & 82 \\
\hline
\end{tabular}

Based on table 4 , it can be seen that the production value of the ikat business produced by ikat entrepreneurs in Troso Village, Jepara has the largest frequency of 46 entrepreneurs with production values ranging from Rp. 11,200,000 to Rp. 18,899.999, while the smallest frequency is one entrepreneur. With a production value ranging from $34,300,000$ to 
$42,000,000$ while the mean (average) production value of the ikat business in Troso Village, Jepara is Rp. $17,706,097.56$.

\subsection{Clasic Assumption Test}

\subsubsection{Normality Test}

The normality test in this study uses the Kolmogorov-Sminov (KS) non-parametric statistical test and normal probability plots with the help of the IBM SPSS Statistics 21 Program. 0.05 then the research data is normally distributed. The results of the normality test are presented in the table below:

Table 5. Normality Test Results with One-Sample Kolmogorov-Smirnov Test

\begin{tabular}{ll}
\hline $\begin{array}{l}\text { One-Sampel } \\
\text { Kolmogorov-Smirnov } \\
\text { Test }\end{array}$ & $\begin{array}{l}\text { Unstandardized } \\
\text { Residual }\end{array}$ \\
\hline Kolmogorov-Smirnov Z & 0,831 \\
Asymp. Sig. (2-tailed) & 0,495
\end{tabular}

Based on table 5, the Kolmogorov-Smirnov (K-S) value is 0.831 and the significance is 0.495 , which means $>0.05$. Then this indicates that this study is normally distributed and can be used to analyze a problem under study.

In addition, the normality test is also supported by the results of normal probability plots using the IBM SPSS Statistics 21 program so that the following image is obtained:

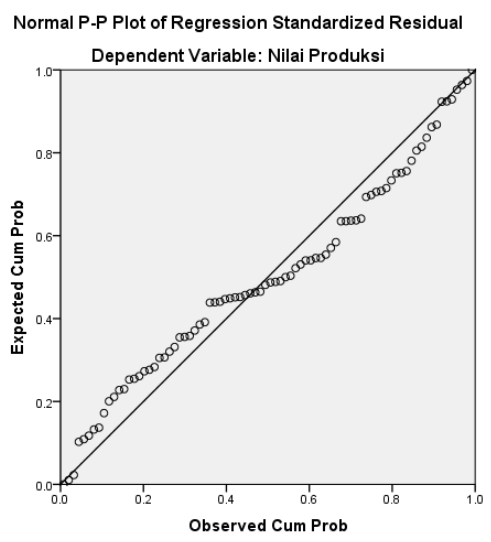

Figure 1. Normality Test Results with normal probability plots

Based on Figure 1, the results of the normality test using normal probability plots show that the data points are seen to spread around the diagonal line and follow the direction of the diagonal line so that it can be said that the data is normally distributed or close to normal, which means that the regression model used fulfills the assumption of normality.

\subsubsection{Linearity Test}

The linearity test aims to determine whether the relationship between the independent variable and the dependent variable is linear or not. Decision-making is based on the value of sig. deviation from linearity, if the significance value $>=0.05$, there is a linear relationship between the independent and dependent variables. Linearity test results are presented in the table below:

Table 6. Linearity Test Result

\begin{tabular}{llll}
\hline No & X impact to Y & $\begin{array}{l}\text { Significant } \\
\text { (Linearity) }\end{array}$ & Result \\
\hline 1 & $\begin{array}{l}\text { Labor Wage } \\
\text { Cost to } \\
\text { production } \\
\text { value }\end{array}$ & 0,076 & Linear \\
2 & $\begin{array}{l}\text { Creativity in } \\
\text { production }\end{array}$ & 0,679 & Linear \\
\hline
\end{tabular}

Based on table 6 , it can be seen that the linearity test results show that the significance value (Linearity) for the variable cost of labor wages is $0.076>0.05$ and the creativity variable is $0.679>0.05$. These results show that the variable cost of labor wages and the creativity variable have a linear relationship to the production value variable because each independent variable has a significance value smaller than 0.05 .

\subsection{Multicollinearity Test}

The multicollinearity test aims to test whether there is a correlation between the independent variables in the regression. Decision-making in this study uses the value of the Variance Inflation Factor (VIF). If the VIF value is less than 10 then the regression is free from multicollinearity, whereas if the VIF value is more than 10 then the regression model occurs multicollinearity. A good regression model should not have a correlation between the independent variables. The results of the multicollinearity test are presented in the table below: 
Table 7. Multicollinearity Test Result

Variable
(constanta)
Ln Labor Wage Cost
Ln Creativity
Based on table 7 the results of the multicollinearity
test show that the production value variable as the
dependent variable for the Labor Wage Cost variable
(X1) has a VIF value of $1.479<10$ with a Tolerance
of $0.676>0.1$ and a VIF value of the creativity
variable (X2) of 1.479 with a Tolerance $0.676>0.1$.
Based on the calculation of the Variance Inflation
Factor (VIF) and Tolerance values of the two variables
above, the VIF value is less than 10 , and the Tolerance
is more than 0.1 meaning that there is no
multicollinearity between the independent variables in
the regression model.

\subsection{Heteroscedasticity Test}

The heteroscedasticity test aims to test whether the regression model in the study has inequality of variance from the residuals of one observation to another observation. In this study, the heteroscedasticity test was carried out by conducting glacier tests and scatterplot graphs with the help of the IBM SPSS Statistics 21 program. Glacier test decision-making is based on the significance value. If the significance value is $<0.05$ then heteroscedasticity occurs oherwise, if the significance value is $>0.05$ then there is no heteroscedasticity. The results of the heteroscedasticity test are presented in the table below:

Table 8. Heteroscedasticity Test Result

\begin{tabular}{ll}
\hline \multicolumn{1}{c}{ Variable } & Signifikansi \\
\hline (constanta) & 0,696 \\
Ln Labor Wage Cost & 0,820 \\
Ln Creativity & 0,665
\end{tabular}

Based on the results of the glacier test, the labor cost variable has a significance value of 0.820 , and the creativity variable has a significance value of 0.665 . The two independent variables have a significance level above 0.05 , so it can be concluded that the regression model does not have heteroscedasticity. In addition, the heteroscedasticity test is also supported by the results of the following scatterplot graph:

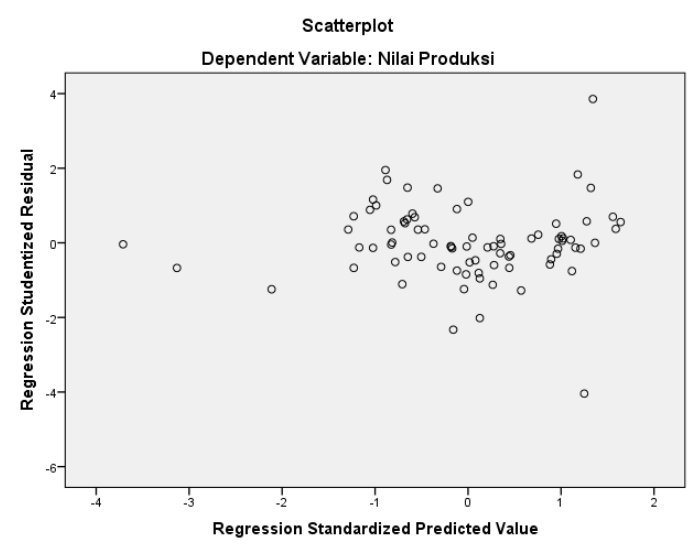

Figure 2 Heteroscedasticity Test

Based on Figure 2, the results of the heteroscedasticity test using a scatter plot graph show that the data points spread above and below and around the number 0 , the spread of the data points does not form a certain pattern such as wavy, narrowing, then widening above and below the number. 0 on the $\mathrm{Y}$ axis, it can be said that the regression model used does not occur heteroscedasticity.

\subsection{Multiple Linear Regression Analysis}

Multiple linear regression analysis was used to determine the direction of the relationship between the independent variable and the dependent variable. The regression equation can be seen in the coefficient table based on the SPSS output between the independent variables, namely Labor Wage Costs and creativity on the dependent variable, namely the production value of the ikat business in Troso Village, Jepara, which is presented in the table below:

Table 9. Multiple Linear Regression Analysis Result

\begin{tabular}{|c|c|c|c|}
\hline \multirow[t]{2}{*}{ Model } & \multicolumn{2}{|c|}{$\begin{array}{l}\text { Unstandardized } \\
\text { Coefficients }\end{array}$} & \multirow{2}{*}{$\begin{array}{l}\text { Standar } \\
\text { dized } \\
\text { Coeffici } \\
\text { ents } \\
\text { Beta }\end{array}$} \\
\hline & B & $\begin{array}{l}\text { Std. } \\
\text { Error }\end{array}$ & \\
\hline (Constant) & 2,155 & 0,409 & \\
\hline $\begin{array}{l}\text { Ln Labor Wage } \\
\text { Cost }\end{array}$ & 0,924 & 0,031 & 0,985 \\
\hline Ln Creativity & $-0,071$ & 0,088 & $-0,027$ \\
\hline
\end{tabular}

Based on the results of multiple linear regression in Table 9, the following regression equation is obtained: 
$\operatorname{LnY}=2,155+0,924 \operatorname{LnX} 1-0,071 \operatorname{LnX} 2+e$

The regression equation has the following meaning:

1. Constant (a) is 2.155 , which means that if the variable cost of labor wages and creativity is assumed to be equal to zero or considered constant, then the variable value of the production value of the ikat business in Troso Village, Jepara is 2.155 .

2. The regression coefficient for the variable cost of labor wages $(\mathrm{LnX} 1)$ is 0.924 . This shows that the cost of labor costs has a positive value on the production value of the ikat weaving business in Troso Village, Jepara. This means that every $1 \%$ increase in labor costs will increase the production value of the ikat weaving business in Troso Village, Jepara, by $0.924 \%$ with the assumption that the other independent variables are fixed.

3. The creativity regression coefficient $(\operatorname{LnX} 2)$ is 0.071 . This shows that creativity has a negative value on the production value of the ikat business in Troso Village, Jepara. This means that every $1 \%$ increase in creativity will decrease the production value of the ikat weaving business in Troso Village, Jepara, by $-0.071 \%$ with the assumption that the other independent variables are fixed.

\subsection{Hypothesis Testing t. Test}

The partial hypothesis test ( $\mathrm{t}$ test) in this study was conducted to test how the influence of labor costs and creativity individually or partially affects the production value of the ikat business in Troso Village, Jepara by assuming other variables are constants. The decision-making rules are:

1. If the significance value of $t<(0.05)$ or tcount $>$ ttable then $\mathrm{H} 0$ is rejected and $\mathrm{Ha}$ is accepted, which means that partially the cost of labor wages $(\mathrm{X} 1)$ and creativity (X2) affect the production value $(\mathrm{Y})$.

2. If the significance value of $t>(0.05)$ or tcount $<$ ttable then $\mathrm{H} 0$ is accepted and $\mathrm{Ha}$ is rejected, which means that partially the cost of labor wages (X1) and creativity (X2) has no effect on the production value $(\mathrm{Y})$.

The t-test in this study was assisted by the IBM SPSS Statistics 21 program with the results presented in the table below:
Table 10. Partial Hypothesis Test Results (t-Test)

\begin{tabular}{ccc}
\hline Model & $\mathrm{T}$ & Sig. \\
\hline (Constant) & 5,274 & 0,000 \\
Ln Labor Wage & 29,839 & 0,000 \\
Cost & & \\
Ln Creativity & $-0,811$ & 0,420 \\
\hline
\end{tabular}

Based on table 10, the significance value of the $t$ test for each independent variable is interpreted as follows:

\subsubsection{Labor Wage Cost}

The cost of labor wages (X1) as an independent variable has a significance of $0.000<0.05$ and has a $t$ count value as shown in table 7 , which is 29.839 while the $t$ table for the number of respondents 82 has a value of 1.99 , so it can be concluded that $t$ count is greater than $\mathrm{t}$ table, which means that partially there is a positive influence on the cost of labor wages on the production value of the ikat business in Troso Village, Jepara.

\subsubsection{Creativity}

Creativity (X2) as an independent variable has a significance value of $0.420>0.05$. It has a tcount value, as shown in table 7 which is -0.811 . In contrast, the $t$ table for the number of respondents 82 has a value of 1.99 so it can be concluded that $t$ count is smaller than $t$ table which means that part there is a negative influence of creativity on the production value of the ikat weaving business in Troso Village, Jepara.

Thus, the cost of labor wages entered into the model shows a significant positive effect and creativity shows an insignificant result so that it has a negative effect.

\subsection{Simultaneous Significance Test (F)}

The F-test was conducted to determine the effect of the variable cost of labor wages on the production value of the ikat business in Troso Village, Jepara. The rules of decision making in the $\mathrm{F}$ test are as follows:

1. If Fcount is significant at $<5 \%$ or Fcount $>$ Ftable, then $\mathrm{HO}$ is rejected and $\mathrm{Ha}$ is accepted, meaning that the cost of labor wages (X1) and creativity (X2) have a joint or simultaneous effect on the production value (Y). ).

2. If Fcount is significant at level $>5 \%$ or Fcount < Ftable, then H0 is accepted and $\mathrm{Ha}$ is rejected, meaning that simultaneously the cost of labor wages (X1), and creativity (X2) have no effect simultaneously or simultaneously on the production value. . 
The $\mathrm{F}$ test in this study was assisted by the IBM SPSS Statistics 21 program with the results presented in the table below:

Table 11. Simultaneous Hypothesis Test Results (Test F)

\begin{tabular}{lllll}
\hline Model & Df & F & Sig. \\
\hline Regression & 2 & 638,40 & 0,000 & \\
& & 1 & & \\
Residual & 79 & & & \\
Total & 81 & & &
\end{tabular}

Based on table 11, it can be seen that the value of F count $>$ Ftable is $638.401>3.96$. This shows that the variable cost of labor wages and creativity simultaneously affect the variable value of production. The result of the significance of $0.000<0.05$, the cost of labor and creativity significantly affects the production value of the ikat weaving business in Troso Village, Jepara. From these results, it can be seen that $\mathrm{Ho}$ is rejected and $\mathrm{Ha}$ is accepted so that $\mathrm{H} 3$, which states that there is a positive influence on the cost of labor wages and creativity simultaneously on the production value is declared accepted.

\subsection{Coefficient of Determination Analysis (R2)}

The coefficient of determination test (R2) was used to measure the contribution of the variable cost of labor wages and creativity to the production value of the ikat business in Troso Village, Jepara. The amount of contribution can be known by looking at the value of the determinant coefficient on the SPSS output in the Model Summary table column R Square. The value of R Square (R2) is converted into percentage form. The IBM SPSS Statistics 21 program assisted the coefficient of determination test in this study with the results presented in the table below:

Table 12. Coefficient of Determination Analysis (R2)

\begin{tabular}{rlrr}
\hline Model & R & R Square & Adjusted R Square \\
\hline 1 & 0,970 & 0,942 & 0,940 \\
\hline
\end{tabular}

Based on table 12, it is known that the value of $\mathrm{R}$ Square is 0.942 (94.2\%) where it means that $94.2 \%$ of the variable production value of the ikat weaving business in Troso Village, Jepara is explained by the variable costs of labor wages and creativity. Other factors outside the model explain the remaining $5.8 \%$.

\subsection{The Effect of Labor Costs on the Production Value of the Ikat Weaving Business in Troso Village, Jepara}

The cost of labor wages referred to in this study is the payment given to all workers as remuneration from ikat entrepreneurs in Troso Village, Jepara. The cost of labor wages in this study was measured by looking at the total amount of wages earned by multiplying the number of workers, the number of units produced by workers and the wages per unit of products sold by ikat entrepreneurs in Troso Village for 1 week and expressed in rupiah.

The wages paid by ikat entrepreneurs in Troso Village, Jepara use the wholesale system. Weaving workers get wages according to the units of goods that have been produced. Usually, the troso ikat workers will deposit their work once a week. The entrepreneur will give the work wages according to the calculation of the units of goods produced and based on the initial agreement.

The regression results show that the regression coefficient LnX1 (Log of Labor Wage Costs) is 0.924. This shows that the cost of labor wages has a positive value on the production value of the ikat weaving business in Troso Village, Jepara, meaning that every $1 \%$ increase in labor costs will increase the production value of the ikat weaving business in Troso Village, Jepara by $0.924 \%$ with the assumption creativity variable is a fixed value. In addition, these results also show that the cost of labor wages contributes to the production value of the ikat business in Troso Village, Jepara.

Based on hypothesis testing, the cost of labor wages (X1) shows the t count value of 29.839 and has a significance value of $0.000<0.05$. This indicates that the cost of labor wages has a positive and significant effect on the production value of the ikat business in Troso Village, Jepara. This means that if the wages given by employers to weaving workers are higher, then workers will be attracted to work for these entrepreneurs so that the number of workers increases and the production value of the weaving business also increases. On the other hand, if the wages given by the weaving entrepreneur are low, then the workers have no interest in working for the weaving entrepreneur and prefer to work elsewhere so that the number of workers can decrease and the production value of the weaving business will also decrease.

The results of this study are in line with the results of research conducted by [3] regarding the Factors Affecting the Production Value of the Furniture Industry in Jeumpa District, Bireun, which states that the cost of labor wages has a positive and significant effect on the production value with a probability $\mathrm{t}$ value $<0.05$ with a value of 0.000 .

In addition, the results of this study are also in accordance with the results of research conducted by [4] regarding the Effect of Capital, Wage Levels, Raw Materials, and Business Experience on the Production 
Value of the Furniture Industry in Makassar, which states that the wage level variable has a positive and significant effect on the production value. With a significance probability $t$ value of $<0.05$ with a value of 0.047 . The results of [4] also state that workers in carrying out their duties will be motivated and produce even more actively if they receive adequate rewards or wages.

So that it can be interpreted that providing appropriate wages for workers will increase the total value of production because it is directly related to the workforce who has the main contribution in the production process. Thus, if ikat entrepreneurs in Troso Village, Jepara provide higher wages to weaving workers, then this can motivate workers to have high work morale so that production output and quality of goods increase so that in addition to having an impact on increasing production results, it will also increase production output. Impact on the production value of the ikat business in Troso Village, Jepara.

\subsection{The Effect of Creativity on the Production Value of Ikat Weaving Business in Troso Village, Jepara}

Products with a high level of creativity will more easily attract consumers to glance at the product because it is different from the others or is something new. If many consumers are interested in a product, the demand for that product will increase and this will increase production. The creativity possessed by troso weaving entrepreneurs is not evenly distributed. Some ikat entrepreneurs in Troso Village, Jepara have high creativity, they have various products and the motifs used also vary and come from their own ideas, but some entrepreneurs have not thought of adding to their weaving products and weaving motifs. because they think that using new motifs created by themselves will not sell well in the market, they still use old motifs known by most consumers and produce only those selling well in the weaving market.

The regression results show that the $\mathrm{LnX} 2$ regression coefficient (Creativity Log) is -0.071 . This shows that creativity has a negative value on the production value of the ikat business in Troso Village, Jepara. This means that every $1 \%$ increase in creativity will reduce the production value of the ikat weaving business in Troso Village, Jepara, by $0.071 \%$ with the assumption that the variable cost of labor costs is fixed. In addition, these results also show that creativity has no contribution to production value.

Based on the creativity hypothesis testing (X2), the $\mathrm{t}$ count value is -0.811 and has a significance of $0.420>0.05$. This shows that creativity has a negative and insignificant effect on the production value of the ikat weaving business in Troso Village, Jepara. Based on these results, it shows that the creativity possessed by weaving entrepreneurs does not contribute to the production value of the ikat business in Troso Village, Jepara. This is because most of the weaving entrepreneurs in Jepara produce weaving based on consumer orders and make weaving motifs based on the trend of motifs in demand in the market. In addition to this, creativity does not affect the production value of torso webbing because several other variables are factors of production, such as capital, raw materials, and technology.

\subsection{The Effect of Labor Costs and Creativity on the Production Value of Ikat Weaving Business in Troso Village, Jepara}

Based on the coefficient of determination test (R2), it is known that the R Square value is 0.942 (92.4\%), which means that $92.4 \%$ of the variable production value of the weaving business in Troso Village, Jepara is explained by the variable costs of labor and creativity. Other factors outside the model explain the remaining $5.8 \%$.

Based on the results of the simultaneous significance test $(\mathrm{F})$ it shows that the significance value of the $\mathrm{F}$ test is less than 0.05 , which is 0.000 , which means that the variable cost of labor wages and creativity together has an effect on the production value of the weaving business in Troso Village, Jepara and has a positive influence.

\section{CONCLUSION}

Based on the study results, it can be concluded that there is a positive and significant effect on the variable cost of labor wages on the production value of the ikat business in Troso Village, Pecangaan District, Jepara. Based on the results of the regression analysis, the coefficient value of labor wages was 0.924 with a significance of $0.000<0.05$, which means that if the variable labor costs increased by 1 percent, it would increase the production value in the ikat business by 0.924 percent. The higher the wage given by the entrepreneur to the weaving worker, the higher the production value of the ikat weaving business. Therefore the ikat entrepreneur should pay more attention to the wages of the weaving worker so that the workers have a high work spirit so as to increase the production value of the weaving business, not only meet the UMR of Jepara. Meanwhile, creativity negatively influences the production value of the ikat weaving business in Troso Village, Jepara. Based on the results of the regression analysis, the creativity coefficient value is -0.071 with a significance of 0.420 
$>0.05$, which means that if the creativity variable has increased by 1 percent, it will reduce the production value in the ikat business by 0.071 percent.

There is a positive and significant effect between the variable cost of labor wages and creativity on the production value of the ikat business in Troso Village, Pecangaan District, Jepara. The magnitude of the influence of the variable cost of labor wages and creativity is seen in the value of the coefficient of determination (R2) which is 0.942 , which means that the variable cost of labor wages and creativity affects the production value of the ikat weaving business in Troso Village, Pecangaan District, Jepara by $94.2 \%$ while 5 The other $.8 \%$ were influenced by other factors not included in this study.

\section{REFERENCES}

[1] Badan Pusat Statistika. Jepara Dalam Angka 2019. Jepara : BPS Kabupaten Jepara. 2019.

[2] Du, Pengcheng., \& Shuxun Wang. The effect of minimum wage on firm markup: Evidence from China. Journal Pre-proof. https://doi.org/10.1016/j.econmod.2019.10.012.

[3] Hadiyati, Ernani. Kreativitas danInovasi Pengaruhnya Terhadap Pemasaran Kewirausahaan Pada Usaha Kecil. Jurnal Inovasi dan Kewirausahaan,Vol 1 No 3. Malang : Universitas Gajayana. 2012.

[4] Hamka. Pengaruh Modal, Tingkat Upah, Bahan Baku, dan Pengalaman Usaha Terhadap Nilai Produksi Industri Meubel Di Kota Makassar. Skripsi. Makassar : Fakultas Ekonomi dan Bisnis Islam UIN Alaudin Makassar. 2019.

[5] Janah, N., Pengaruh Modal, Tenaga Kerja, Dan Teknologi Terhadap Hasil Produksi Monel (Studi Kasus Industri Monel di Kabupaten Jepara). Skripsi. Semarang : Universitas Negeri Semarang. 2017.

[6] Joesron, Suhartati \& Fathorrozi. Teori Ekonomi Mikro. Jakarta : Salemba Empat. 2003.

[7] Pemerintah Indonesia. Undang-undang no. 13 tahun 2003 tentang Ketenagakerjaan. Lembaran RI Tahun 2003 No 13. Jakarta :Sekretariat Negara. 2003.

[8] Rosyidi, S., Pengantar Teori Ekonomi; Pendekatan kepada Teori Ekonomi Mikro \& Makro. Jakarta: RajaGrafindo Pustaka. 2006.
[9] Scarborough, Norman., Wilson, Doug., Zimmerer, Thomas. (2008). Kewirausahaan dan Manajemen Usaha Kecil. Terjemahan Deny Arnos Kwary. Jakarta : Salemba Empat.

[10] Suryana. Kewirausahaan Pedoman Praktis: Kiat dari Proses Menuju Sukses Edisi Ketiga. Jakarta : Salemba Empat. 2006. 